\title{
Android-based Teaching Material for Statistics Integrated with Social Media WhatsApp
}

\author{
1Anggit Prabowo, 2Uki Rahmawati, 1Rostien Puput Anggoro \\ ${ }^{1}$ Universitas Ahmad Dahlan, Jl. Ringroad Selatan, Kragilan, Banguntapan, Bantul, Yogyakarta 55191, Indonesia \\ ${ }^{2}$ Southeast Asian Minister Education Organization (SEAMEO) Regional Centre for Quality Improvement of \\ Teachers and Education Personnel (QITEP) in Mathematics, Sleman, Yogyakarta, Indonesia \\ e-mail: anggit.prabowo@pmat.uad.ac.id
}

\begin{abstract}
The purpose of this study was to develop teaching material in the form of Android-based application for junior high school mathematics subjects in statistical material that are integrated with WhatsApp social media platform. The procedure for developing teaching materials was carried out through the stages of defining, designing, developing, and disseminating. The platform used to develop teaching material was MIT App Inventor. The teaching materials developed have been validated by two media experts and material experts. The trial of teaching material was carried out to educators and prospective mathematics educators in the Special Region of Yogyakarta and students at Depok 3 State Junior High School. This study has succeeded in developing Android-based teaching materials for junior high school mathematics subjects in valid and effective statistical material. The menus contained in this application consist of material and competency test. On the competency test menu, students can do the test and after completion, the application will display the score of the test results. What interesting about this application, the test results can be sent to the teacher via WhatsApp.
\end{abstract}

Keywords: Android, Teaching Material, Statistics, WhatsApp

How to Cite: Prabowo, A., Rahmawati, U., \& Anggoro, R.P. (2019). Android-based Teaching Material for Statistics Integrated with Social Media WhatsApp. International Journal on Emerging Mathematics Education, 3(1), 93-104. http://dx.doi.org/10.12928/ijeme.v3i1.11961

\section{INTRODUCTION}

Statistics is the science associated with data in the form of measuring, constraining, and communicating it (Davidian \& Louis, 2012). In Indonesia, statistics is one of the topics studied in mathematics. The material began to be studied by students since the 9th grade of middle school. The statistical material studied in junior high school includes the presentation of data, the size of the data centre, and the size of the data distribution. Data from the Ministry of Education and Culture of the Republic of Indonesia in 2016 and 2017 shows that mathematics is the most difficult subject for junior high school students to understand compared to other subjects (English language, Indonesian language, and science). In 2016 the national examination average for junior high school mathematics subjects was 53.39 and in 2017 it dropped to 47.75 .

The junior high school mathematics material tested at the national exam in junior high school includes numbers, algebra, geometry and measurement, statistics and probability. The report of the analysis from year to year regarding the mathematics material that is most difficult to learn for junior high school students is presented in Table 1. 
Table 1. The hardest material for Mathematics based on National Examination Results

\begin{tabular}{clc}
\hline Year & \multicolumn{1}{c}{ Hardest Material } & Percentage \\
\hline 2013 & Elements, properties of three-dimensional shape & 50.92 \\
2014 & Statistics: presentation of data and size of concentration & 58.01 \\
2015 & Geometry & 52.04 \\
2016 & Statistics dan probability & 46.73 \\
\hline
\end{tabular}

Based on Table 1, it can be seen that statistics is the most difficult material in two years from 2013 to 2016 . The difficulty of the systematic material learned by students is also evidenced from the results of the Koparan's study (2015) that middle school students have difficulty understanding statistical concepts (Watson, 2006; BenZvi \& Garfield, 2004). In fact, except students, teachers also have difficulties in statistical material (Saughnessy \& Zawojewky, 1999).

One of the factors that influence students' academic performance is the availability of adequate teaching materials. The results of Mbugua's study (2012) shows that teaching materials that are inadequate make students unable to understand mathematical material optimally. More specifically, the factors that influence students' academic abilities in statistics, one of which is the irrelevance of teaching materials and learning resources (Koparan, 2015). The limitations of teaching materials, the incompatibility of teaching materials with material characteristics, and the inability to access are problems related to teaching materials.

The most common teaching materials used in learning are physical teaching materials such as printed books, textbooks, maps, charts, posters, and models. This type of teaching material has limitations in accessibility because it has a large enough dimension and is not efficient when taken to various places. Students cannot use teaching material at any time. In fact, students will easily learn if they have teaching materials that can be accessed anytime and anywhere (Prabowo, 2018). Thus, it is necessary to develop a flexible teaching material accessible to students.

One of the outcomes of $21^{\text {st }}$-century learning is that both students and teachers have the skills to utilize technological, information and communication facilities in learning. Therefore, elements in learning should be based on information, technology, and communication (ICT). Teachers must be familiar with the use of LCDs, computers, and the internet in learning. Teaching materials used should also be based on technology, information, and communication. It is because students are very familiar with electronic devices based on technology, information, and communication such as laptop or smartphones connected with internet. This is actually not an obstacle because the internet is easily accessible in Indonesia with 88.1 million users (APJII, 2016). In addition, innovation in the development of mobile applications in the world of education continues to increase because this application is able to support the implementation of the learning process (Johnson, et al. 2012; Hsu \& Ching, 2013).

Teaching materials that can access via a smartphone will facilitate students in learning. They can learn whenever and wherever because their teaching materials are in their hands. For this reason, the development of Android-based teaching material for statistical material will make it easier for students to study statistics. The reason for choosing the Android operating system is because this operating system is a very popular operating system developed by large companies in the field of communication, Google (Gilski \& Stefanski, 2015; Setiawan, et al. 2017).

Research on the development of Android-based teaching materials was previously carried out by Amin and Mayasari (2015) who have developed Android-

IJEME, Vol. 3, No. 1, March 2019, 93-104. 
based applications for Statistics material. However, the application which developed is an application for lectures in college. Application development for middle school statistics material has not been conducted. Furthermore, this application will take advantage of the existence of the most popular social media platforms in the community, WhatsApp (Nitza \& Roman, 2016) in one of the menus, namely in the Competency Test menu. WhatsApp can be used to send test results to teachers so that the test procedures carried out are paperless tests.

\section{RESEARCH METHOD}

This research was development research. The product developed in this study is teaching material in the form of an Android-based application for statistics material in junior high school. Figure 1 shows the procedure used in product development in this study that consists of 4 stages namely define, design, define, and disseminate (Thiagarajan, et al. 1974; Prabowo, 2017).

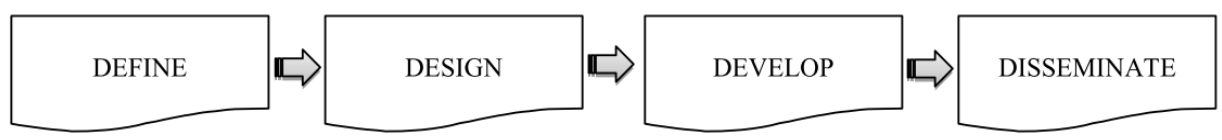

Figure 1. Research Procedure

Application development starts from the need analysis of the importance of developing statistics teaching materials in the form of Android-based applications for junior high school. After that, the researcher designed an application storyboard that contained an overview of the sketch and description of the application in the outline. Based on the storyboard, the main product was developed using the MIT App Inventor platform. At the development stage, the product produced is requested to be evaluated by learning experts and media experts (Thiagarajan, et al. 1974). They evaluated the content validity of the product by checking the suitable about competencies to be achieved with the material. After getting the assessment and improvement, the product is then tested to students at Depok 3 State Junior High School to get responses from students and test the effectiveness. After getting a response from students, the product was revised based on the results of the trial. Furthermore, the products were disseminated to mathematics teachers and prospective mathematics teachers in Yogyakarta. In addition, dissemination is also done by uploading the application in Play store. The instruments of this study are questionnaire and competency test. The questionnaire was used to test product validity. The competency test was used to test the effectiveness of the product which consists of 10 multiple choice questions with 4 options. The product is effective when all students get score minimum 75 at competence test.

\section{RESULTS AND DISCUSSION}

The development of teaching materials of Android-based applications for junior high school statistics is based on the results of documentation in the field which shows that mathematics is the most difficult subject to understand in junior high school students in Indonesia and statistics is one of the most difficult material. Report of Indonesia Ministry of Communication and Information shows that the number of mobile users in Indonesia is quite large, which is equal to $84.4 \%$ of Indonesia's population (Ministry of Communication and Information, 2016; Prabowo, 2018). Unfortunately, the activities that teenage students do with their mobile phones are 
activities that are not related to learning activities such as chat, social media, and playing games (Muflih, et al. 2017). The use of smartphones to access educational content is the third choice after social media, entertainment, and news (APJII, 2016). For this reason, there is a need to make use of the smartphone owned by students to support learning activities. One of them is by utilizing smartphones as students' learning resources. The product developed in this study is an application that contains SMP statistical teaching material that can be installed on a smartphone with the Android operating system.

After the product defined, the next step was designing the displays on the application using the MIT App Inventor platform presented in Figure 2.

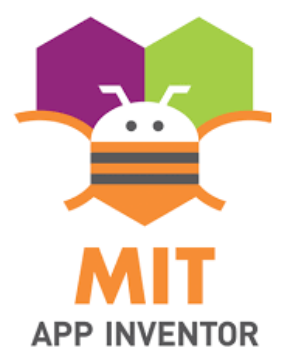

Figure 2. MIT App Inventor Platform Icon

MIT App Inventor is a platform for creating open source web-based applications originally developed by Google, and currently managed by the Massachusetts Institute of Technology (MIT) (Abeywardena, 2015). App Inventor allows beginner users to create an Android-based application. The main designs of this application are shown in Figure 3.

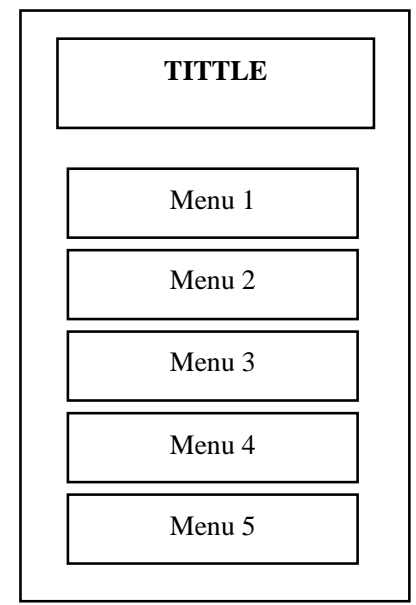

Figure 3. Application Design

In the main page of the application consists of title and menu buttons 1 to 5 . The title of the application is STATISTIKA, to describe the material content. Menu 1 contains material about Penyajian Data (Data collection). The material Penyajian Data consists of Definition of data and statistics, population and samples, and presentation of data in various forms (tables, bar charts, line diagrams, and pie charts). Menu 2 contains material about Ukuran Pemusatan Data. This menu consists of mean, mode, and median. Menu 3 contains material about Ukuran Penyebaran Data. This menu consists of range and quartile. Menu 4 contains Latihan dan Pembahasan. This menu 
contains items test and the solution. Menu 5 contains Uji Kompetensi. This menu displays 10 multiple choice test questions consisting of 4 answer choices. This menu contains test questions related to the material.

The next application design was developed with the Android application development tool, MIT App Inventor. The main appearance of the design after being developed is as shown in Figure 4.

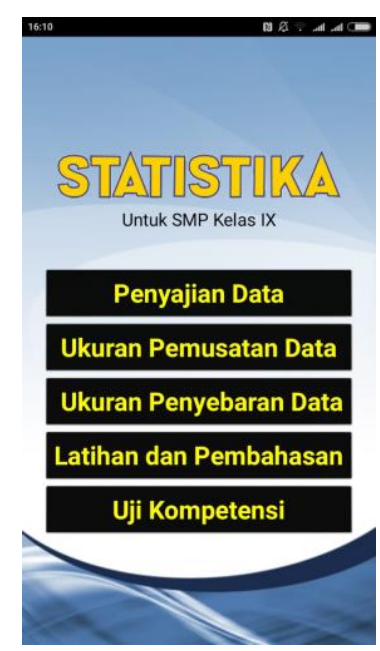

Figure 4. Initial Display of Android-Based Learning Materials for Statistics Material

The menus on this display are a button so that when the menu is touched it will display a new page whose contents are related to the menu title. Table 2 is the menu tables and pages that are displayed when the menu is selected.

Table 2. Menus on the Application

\begin{tabular}{|c|c|c|c|c|}
\hline Menu & Figure & Menu & \multicolumn{2}{|c|}{ Figure } \\
\hline \multirow{16}{*}{$\begin{array}{l}\text { Penyajian } \\
\text { Data } \\
\text { (Data } \\
\text { Display) }\end{array}$} & penysajaian_data & \multirow{16}{*}{$\begin{array}{c}\text { Latihan dan } \\
\text { Pembahasan } \\
\text { (Exercises and } \\
\text { Discussion) }\end{array}$} & \multicolumn{2}{|c|}{ |rass } \\
\hline & 1. Pengertian Data dan Statistika & & \multirow{2}{*}{\multicolumn{2}{|c|}{$\begin{array}{l}\text { Soal 1: } \\
\text { Tentukan mean, modus, dan median data pac } \\
\text { berikut! }\end{array}$}} \\
\hline & $\begin{array}{l}\text { Data merupakan kumpulan datum, di mana } \\
\text { datum merupakan fakta tungagal. Untuk }\end{array}$ & & & \\
\hline & $\begin{array}{l}\text { elebin helasnnava pelaarar uralan enerinut. } \\
\text { Statistika adalah ilmu yang berhubungan }\end{array}$ & & & Freckunsi \\
\hline & $\begin{array}{l}\text { dengan pengumpulan data, perhitungan } \\
\text { atau pengolahan data, serta penarikan }\end{array}$ & & \multirow{4}{*}{\begin{tabular}{|c|} 
Nilai $(x)$ \\
5 \\
6 \\
7 \\
8 \\
9 \\
10 \\
\end{tabular}} & \\
\hline & $\begin{array}{l}\text { kesimpulan berdasarkan data yang } \\
\text { diperoleh. }\end{array}$ & & & \\
\hline & Perhatikan data berikut! & & & 8 \\
\hline & 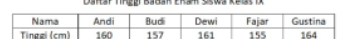 & & & \\
\hline & Berdasar tabel di atas, tinggi Andi 160 & & \multirow{6}{*}{\multicolumn{2}{|c|}{ 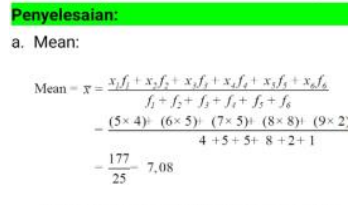 }} \\
\hline & cm. Fakta tunggal ini dinamakanan datum. & & & \\
\hline & $\begin{array}{l}\text { enam siswa disebut data. Berdasar data } \\
\text { tersebut dapat disimpulkan bahwa Gustina }\end{array}$ & & & \\
\hline & 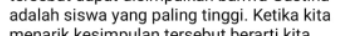 & & & \\
\hline & $\begin{array}{l}\text { menanark kesimpunan tersebut berarti kita } \\
\text { sudah menggunakan statistika. }\end{array}$ & & & \\
\hline & 2. Populasi dan Sampel & & & \\
\hline & $\begin{array}{l}\text { Populasi iadalah totalitas dari semua objek } \\
\text { atau individu yang memilikik karakteristik }\end{array}$ & & \multirow{2}{*}{\multicolumn{2}{|c|}{$\begin{array}{l}\text { Jadi, mean dari data tersebut adalah } 7,08 \text {. } \\
\text { b. Modus } \\
\text { Pada tabel terlihat bahwa nilai yang paling }\end{array}$}} \\
\hline & $\begin{array}{l}\text { tertentu, jelas, dan lengkap yang akan } \\
\text { ten }\end{array}$ & & & \\
\hline
\end{tabular}




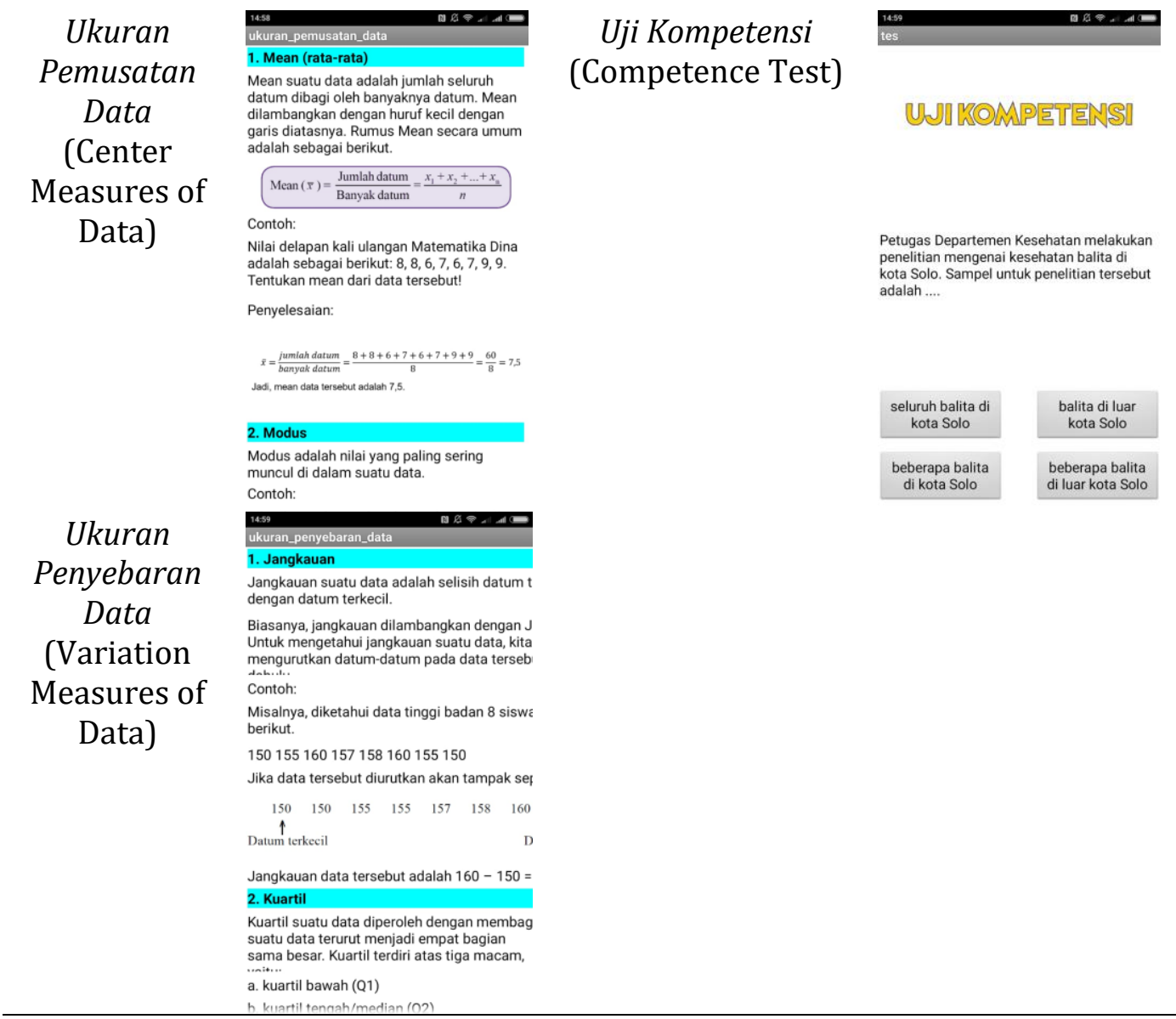

Activities at the next development stage are product assessments carried out by material experts and media Based on an evaluation by material experts, the materials described in the product were in accordance with the competencies to be achieved. The material and test presented in the product were statistical material that consists of data display, centre measures of data, and various measures of data. The expected competencies of product development were students able to understand statistical concepts and solve problems related to statistics in junior high school. Furthermore, material experts provided a suggestion for applications developed especially on the Uji Kompetensi menu. They stated that to increase the sincerity of students in working on questions, scoring should be done by giving a score on the correct answer and giving a score reduction on the wrong answer. That way students do not carelessly do the questions.

Suggestions from media experts are followed up by revising the scoring guidelines on the questions in the competency test. The number of questions in the Competency Test is 8. Scoring is done by giving an additional score of 12.5 if the question is answered correctly and -5 if the question is answered incorrectly as shown in the following syntax presented in Figure 5. 


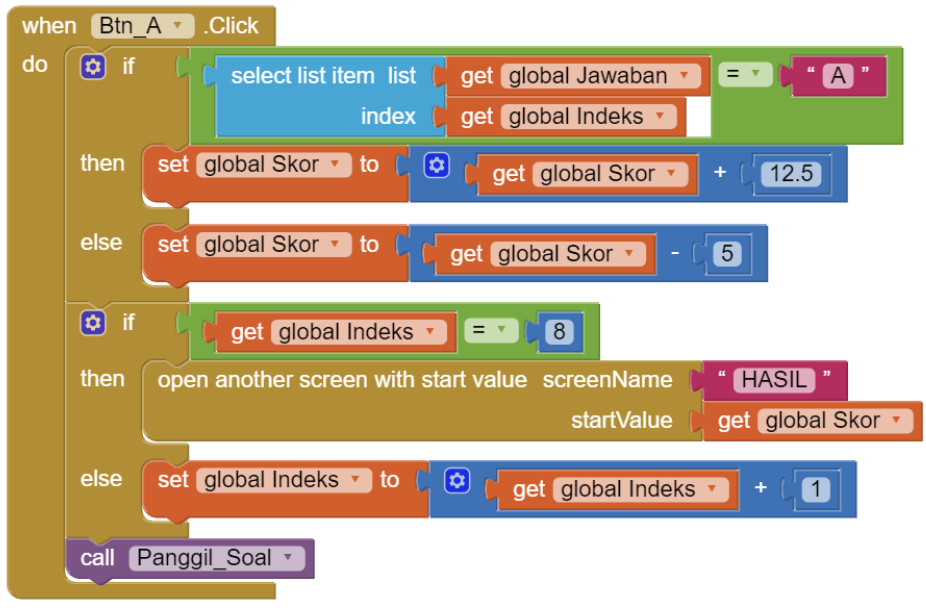

Figure 5. Syntax of Scoring

Media experts stated that the composition of colours in the application provides a comfortable viewing angle for the user. Competency test questions should not use a combination of complex background colours so as not to disturb the concentration of students when working on the questions. The results of expert appraisal indicate that the two experts stated that the products developed were suitable for use in learning mathematics in junior high school statistical material.

After the product was revised, it was then tried on the learning of mathematics in junior high school. The results of the trial show that the application developed is easy to operate and able to provide additional flexible learning resources. To find out the effectiveness of teaching materials in improving learning outcomes in statistical material, effectiveness tests were conducted by comparing the results of competency tests with the minimum school completeness criteria value of 75. After being tested, the application was disseminated to junior high school mathematics teachers in Yogyakarta and students of mathematics education study programs as a prospective mathematics educator.

\section{Study Anytime and Anywhere}

Teaching materials used by teachers in teaching are usually the main learning resources for students. One of the learning resources provided by the school is a book. The book used to support learning in educational units consists of textbooks and non-learning textbooks (Regulation of the Minister of Education and Culture of the Republic of Indonesia Number 8 of 2016, 2016). Textbooks are the main learning resource for achieving basic competencies and core competencies and are declared appropriate by the Ministry of Education and Culture for use in educational units. Nontext lesson books are enrichment books to support the learning process at every level of education and other types of books available in the school library. For the provision of books in schools, the Indonesian government budgeted BOS funds. The books provided at the school belong to the school so students must return the book at the end of the academic year.

If viewed from the flexibility, books have several weaknesses when compared with learning resources in the form of an Android-based application installed on a smartphone. Android-based teaching materials are cheaper and more flexible. From smartphone users in Indonesia, the most favourite operating system is Android (Salbino, 2015). Dimensionally, smartphones are easy to carry everywhere. According to Akpan (2017), mobile phones have the advantage of being affordable, portable and comfortable. 
Accessibility of mobile phones is easier when compared to books. Mobile phones are easy to carry by hand and the internet is always available for 24 hours.

The mobile phone is a portable device for users. That is, wherever and whenever, users can operate mobile phones (Consortium for Media Literacy, 2009; Akpan, et al. 2017). A mobile phone that is used as a learning resource will provide learning convenience for students. They can learn by opening applications on their cell phones when they are at school, on the bus, in the canteen, at home, in other public places. They can operate it day and night. With mobile, it means changing the learning approach of students. The conventional approach is that they only study at school or at home.

\section{Integrated with Social Media WhatsApp}

The results of the We Are Social survey in 2017 (Triastuti, et al. 2017) show that Indonesia's population using social media reached 106 million of the total population of 262 million. WhatsApp is one of the social media platforms in the form of smartphone applications for sending short messages (Nitza \& Roman, 2016). People use this application because of its low cost, offering smooth conversations, creating a sense of kinship, and having secrecy unlike social networks (Church \& de Oliveria, 2013). The design is simple but functional (Supratman, 2018). Therefore, this application is very popular with users of social media applications.

Barhoumi (2015) conducted research on the use of WhatsApp in relation learning for the means of sharing between students, improving skills, and facilitating the learning process. The application that has been developed in this study utilizes WhatsApp from the other side of learning, namely in the learning evaluation process. The learning assessment that is generally carried out by teachers in Indonesia is paper and pencil-based evaluation. Students are asked to solve the problem (items test) on paper and then collect them to the teacher. Even, the computer-based national exams were held starting just in 2014. There were only a few pilot projects in the schools, namely Singapore Indonesia Middle School and Kuala Lumpur Indonesian Middle School (Rambe, 2017). National examinations in Indonesia in 2018 there are still 18 provinces which in carrying out national examinations still use paper and pencil.

Application teaching material of statistics offers a scoring system that is done in a paperless manner. The teacher no longer prints the questions sheet. The questions students do are presented in the application on the Uji Kompetensi menu. When students access it, questions will be presented for students on a mobile phone screen. After students answered the questions, the mobile phone screen will display the scores obtained by students. The display of the score is shown in Figure 6.

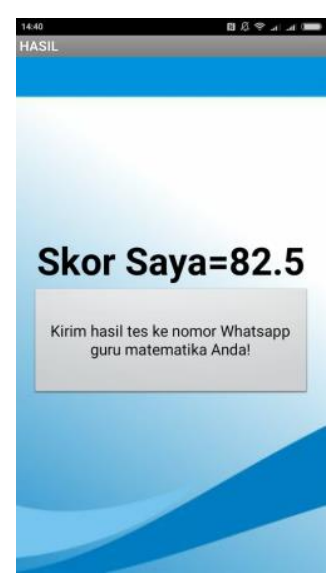

Figure 6. Score Obtained by Students

IJEME, Vol. 3, No. 1, March 2019, 93-104. 
In addition to the scores that appear after students work on the questions, the mobile phone screen will also display a button with the description "Kirim Hasil tes ke nomor WhatsApp guru matematika Anda!" If this button is hit, the mobile screen will be integrated with WhatsApp. It will display the contacts of WhatsApp in students' mobile phone. Later, students can search WhatsApp numbers for the teacher to send the test results they are doing as shown in Figure 7.

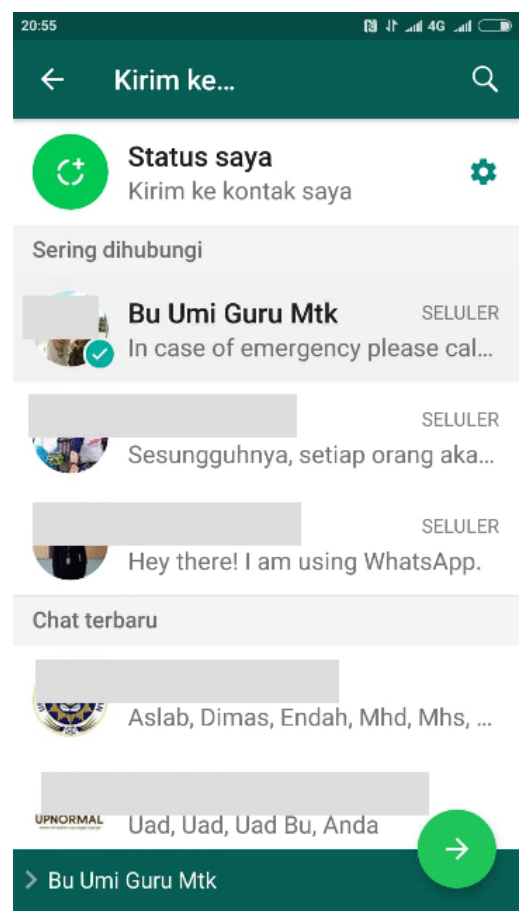

Figure 7. WhatsApp Contacts

With the design of competency tests such as this minimizes the use of paper in carrying out the exam. Teacher states that with an exam like this the test will be effective. Minimizing the use of paper to support forest conservation programs. In addition, the correction is done by the system so that the teacher can just accept the test results. Based on the teacher's opinion, it can be seen that the system tests carried out in the application and integrated with WhatsApp provide benefits for teachers and also the natural environment with minimizing the use of paper made from wood.

\section{CONCLUSION}

This research has developed an Android-based application as a learning resource for students and teaching materials for students in junior high school statistics material. This application can be used by students in learning whenever and wherever. To assess student performance, this application provides a paperless test system and integrates with Whatsapp social media platforms. Through this system, the teacher can receive the test results without needing to correct the students' work.

\section{REFERENCES}

Abeywardena, I.S. (2015). Educational App Development Toolkit for Teachers and Learners. Burnaby: Commonwealth of Learning.

Akpan, V.I. (2017). Cell Phones as Effective Learning Resource. British Journal of Education, Society \& Behavioural Science, 22(4), 1-8. 
Akpan, V.I., Kufre, P., \& Abe, E. (2017). Effectiveness of WhatsApp as a collaborative tool for learning among undergraduate students in University of Uyo, Akwa Ibom state. International Journal of Advanced Education and Research, 2(5), 43-46.

Amin, A.K., \& Mayasari, N. (2015). Pengembangan Media Pembelajaran Berbentuk Aplikasi Android Berbasis Weblog untuk Meningkatkan Hasil Belajar Mahasiswa Pendidikan Matematika IKIP PGRI Bojonegoro. Magistra, 27(94), 12-23.

APJII. (2016). Google: Indonesia surga bagi startup dan perusahaan modal ventura Asean. Buletin APJII, 02.

APJII. (2016). Google: Saatnya jadi perhatian pemerintah dan industri. Buletin APJII, 05.

Barhoumi, C. (2015). The Effectiveness of WhatsApp Mobile Learning Activities Guided by Activity Theory on Students' Knowledge Management. Contemporary Educational Technology, 6(3), 221-238.

Ben-Zvi, D., \& Garfield, J. (2004). The challenge of developing statistical literacy, reasoning, and thinking. Springer: Kluwer Academic Publisher.

Church, K., \& de Oliveira, R. (2013). What's up with WhatsApp? Comparing mobile instant messaging behaviors with traditional SMS. Paper presented at 15 th International Conference on Human-computer interaction with mobile devices and services, ACM, 352-361.

Consortium for Media Literacy. (2009). Cell phones have had a checkered history in schools. CONNECTIONS/MediaLit Moments, 1(10).

Davidian, M., \& Louis, T.A. (2012). Why Statistics? Science, 336(6077), 12. http://dx.doi.org/10.1126/science.1218685

Gilski, P., \& Stefanski, J. (2015). Android OS: A Review. TEM Journal, 4(1), 116-120.

Hsu, Y.C., \& Ching, Y.H. (2013). Mobile App Design for Teaching and Learning: Educators' Experiences in an Online. The International review of research in open and distance learning, 14(2), 117-139.

Johnson, L., Adams, S., \& Cummins, M. (2012). Mobile apps. The NMC horizon report: 2012 Higher Education Edition. Austin, Texas: The New Media Consortium.

Kementerian Komunikasi dan Informatika Republik Indonesia. (2016). ICT Indicators Infographic. Jakarta: Pusat Penelitian dan Pengembangan SDPPPI, Badan Penelitian dan Pengembangan Sumber Daya Manusia, Kementerian Komunikasi dan Informatika.

Koparan, T. (2014). Difficulties in Learning and Teaching Statistics: Teacher Views. International Journal of Mathematical Education in Science and Technology. 46(1), 94-104.

Mbugua, Z.K., Kibet, K., Muthaa, G.M., \& Nkonke, G.R. (2012). Factors Contributing to Students' Poor Performance in Mathematics at Kenya Certificate of Secondary Education in Kenya: A Case of Baringo County, Kenya. American International Journal of Contemporary Research, 2(6), 87-91.

Muflih, Hamzah, \& Puniawan, W.A. (2017). Penggunaan Smartphone Dan Interaksi Sosial Pada Remaja di SMA Negeri I Kalasan Sleman Yogyakarta. Idea Nursing Journal, 8(1), 12-18.

Nitza, D., \& Roman, Y. (2016). WhatsApp Messaging: Achievements and Success in Academia. International Journal of Higher Education, 5(4), 255-261.

Kementerian Pendidikan dan Kebudayaan Republik Indonesia. (2016). Peraturan Menteri Pendidikan dan Kebudayaan Republik Indonesia Nomor 8 Tahun 2016. Jakarta: Kemendikbud 
Prabowo, A., Anggoro, R.P., Astuti, D., \& Fahmi, S. (2017). Interactive multimedia-based teaching material for 3-Dimensional geometry. Journal of Physics: Conf. Series 943(1), 012047.

Prabowo, A., Anggoro, R.P., Adiyanto, R., \& Rahmawati, U. (2018). Interactive Multimedia-based Teaching Material for Trigonometry. Journal of Physics: Conf. Series 1097(1), 012138.

Rambe, Y.S. (2017). The Relationship Between Self Efficacy and Social Support with Student's Anxiety Facing the Computer Based Test (CBT) at SMK PAB 12 Saentis. Analitika, 9(1), 60-68.

Salbino, S. (2015). Pintar gadget android untuk pemula. Jakarta: KunciKom.

Saughnessy, J.M., \& Zawojewky, J.S. (1999). Secondary students' performance on data and chance in the 1996 NAEP. Mathematics Teacher, 92(8), 713-718.

Setiawan, A., Handojo, A., \& Hadi, R. (2017). Indonesian Culture Learning Application based on Android. International Journal of Electrical and Computer Engineering (IJECE), 7(1), 526-535.

Supratman, L.P. (2018). Penggunaan Media Sosial oleh Digital Native. Jurnal Ilmu Komunikasi, 15(1), 47-60.

Thiagarajan, S., Semmel, D.S., \& Semmel, M.I. (1974). Instructional Development for Training Teachers of Exceptional Children: A sourcebook. Minnesota: ERIC.

Triastuti, E., Prabowo, D.A.I., \& Nurul, A. (2017). Kajian Dampak Penggunaan Media Sosial Bagi Anak dan Remaja. Jakarta: Pusat Kajian Komunikasi FISIP Universitas Indonesia.

Watson, J.M. (2006). Statistical Literacy at school, growth, and goals. Mahwah: Lawrence Erlbaum Associates. 
IJEME, Vol. 3, No. 1, March 2019, 93-104. 